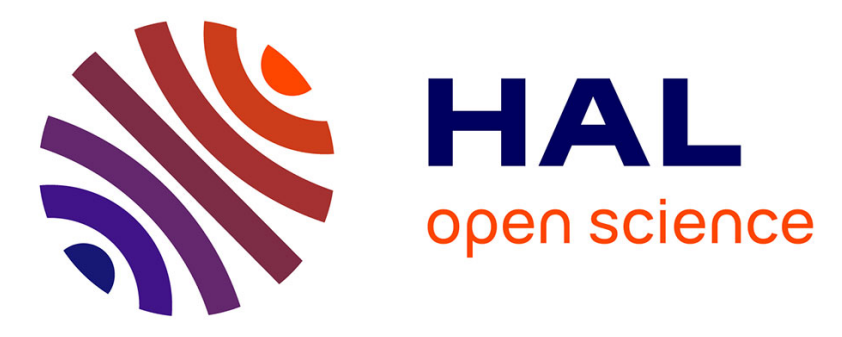

\title{
Evidence of Reactivity in the Membrane for the Unstable Monochloramine during MIMS Analysis
}

Essyllt Louarn, Abdoul Monem Asri-Idlibi, Julien Leprovost, Michel Heninger, Helene Mestdagh

\section{- To cite this version:}

Essyllt Louarn, Abdoul Monem Asri-Idlibi, Julien Leprovost, Michel Heninger, Helene Mestdagh. Evidence of Reactivity in the Membrane for the Unstable Monochloramine during MIMS Analysis. Sensors, 2018, 18 (12), pp.4252. 10.3390/s18124252 . hal-02363575

\section{HAL Id: hal-02363575 https://hal.science/hal-02363575}

Submitted on 14 Nov 2019

HAL is a multi-disciplinary open access archive for the deposit and dissemination of scientific research documents, whether they are published or not. The documents may come from teaching and research institutions in France or abroad, or from public or private research centers.
L'archive ouverte pluridisciplinaire HAL, est destinée au dépôt et à la diffusion de documents scientifiques de niveau recherche, publiés ou non, émanant des établissements d'enseignement et de recherche français ou étrangers, des laboratoires publics ou privés. 
Article

\title{
Evidence of Reactivity in the Membrane for the Unstable Monochloramine during MIMS Analysis
}

\author{
Essyllt Louarn ${ }^{1, *}{ }^{\mathbb{C}}$, Abdoul. Monem Asri-Idlibi ${ }^{1}$, Julien Leprovost ${ }^{2}$, Michel Héninger ${ }^{1}{ }^{1}$ and \\ Hélène Mestdagh ${ }^{1}$ \\ 1 Laboratoire de Chimie Physique, UMR 8000, CNRS et Université Paris Sud, 91405 Orsay, France; \\ idlibi.im@gmail.com (A.M.A.-I.); michel.heninger@u-psud.fr (M.H.); helene.mestdagh@u-psud.fr (H.M.) \\ 2 AlyXan, Centre Hoche, 3 Avenue Condorcet, 91260 Juvisy-sur-Orge, France; julien.leprovost@alyxan.fr \\ * Correspondence: essyllt.louarn@u-psud.fr; Tel.: +33-16-915-3884
}

Received: 13 November 2018; Accepted: 30 November 2018; Published: 3 December 2018

\begin{abstract}
Membrane Inlet Mass Spectrometry (MIMS) was used to analyze monochloramine solutions $\left(\mathrm{NH}_{2} \mathrm{Cl}\right)$ and ammonia solutions in a compact FTICR. Chemical ionization enables identification and quantification of the products present in the permeate. The responses of protonated monochloramine and ammonium increase linearly with the solution concentration. The enrichments were respectively 1.2 and 5.5. Pervaporation is dependent on $\mathrm{pH}$ and only the basic form of ammonia $\mathrm{NH}_{3}$ pervaporates through the membrane. Unexpectedly, the small ammonia molecule permeated very slowly. It could be due to interactions with water molecules inside the membrane that create clusters. Moreover, $\mathrm{NH}_{2} \mathrm{Cl}$ solutions, in addition to the $\mathrm{NH}_{3} \mathrm{Cl}^{+}$signal, presented a strong $\mathrm{NH}_{4}{ }^{+}$signal at $m / z 18.034$. Ammonia presence in the low-pressure zone before ionization is probable as $\mathrm{NH}_{4}{ }^{+}$was detected with all the precursors used, particularly $\mathrm{CF}_{3}{ }^{+}$and trimethylbenzene that presents a proton affinity higher than monochloramine. Ammonia may be formed inside the membrane due to the fact that $\mathrm{NH}_{2} \mathrm{Cl}$ is unstable and may react with the water present in the membrane. Those results highlight the need for caution when dealing with chloramines in MIMS and more generally with unstable molecules.
\end{abstract}

Keywords: MIMS; monochloramine; FTICR; chemical ionization; in-membrane reaction; PTRMS; CIMS

\section{Introduction}

Membrane Inlet Mass Spectrometry (MIMS) is an efficient tool to analyze water and air samples from the environment. It has gained interest since it was first reported in 1987 [1] as it allows real-time analysis of water and air samples by mass spectrometry [2] and generally preconcentration of targeted compounds. Its use spans from detection of organics in water to the more recent analysis of nitrites and nitrates [3]. MIMS technology is based on the separation of the analyte stream and the mass spectrometer inlet by a membrane. There are many possible configurations available: from in-vacuum membrane without any carrier gas to external tubular membranes using a dry carrier gas or a solvent, such as in condensed-phase MIMS [2]. Compared to more traditional GC-MS instruments used for volatile organic compounds (VOC) analysis, MIMS results in rapid analysis without complex preparation of the samples [4].

To make the MS easily portable, MIMS is usually associated to an electronic ionization (EI) source such as in underwater mass spectrometry $[5,6]$. The main drawback of the use of EI sources is the complexity of the mixture spectra as EI fragments each molecular ion into a large number of daughter ions, most of them being not specific of the molecule. On the contrary, chemical ionization (CI) methods produce low fragmentation, and then an easy-to-read mass spectrum without further separation [7,8]. In instruments such as Selective Ion Flow Tube (SIFT) [9] or Fourier Transform Ion Cyclotron Resonance (FT-ICR) [10], controlled conditions in the ionization zone enable direct 
quantification of the gas introduced. It is then possible to study the composition of the permeate gas behind the membrane, which gives access to a better understanding of the permeation process occurring during pervaporation and especially to enrichment factors and diffusion speeds.

This technique has been applied to the study of chloramine in water. Chloramination is an efficient way to decontaminate water before its use in public areas such as swimming pools or in refrigeration waters. Chloramine formation is processed by the mixing of an ammonia solution and sodium hypochlorite. Depending on the conditions $(\mathrm{pH}$, temperature, $\mathrm{Cl} / \mathrm{N}$ ratio, ... ), the solution contains monochloramine $\left(\mathrm{NH}_{2} \mathrm{Cl}\right)$, dichloramine $\left(\mathrm{NHCl}_{2}\right)$ or trichloramine $\left(\mathrm{NCl}_{3}\right)$ [11]. Monochloramine is formed for $\mathrm{pH}$ above 6.5. Its formation is optimal for $\mathrm{pH} 8$ at $25{ }^{\circ} \mathrm{C}$. Being highly reactive, monochloramine is the most efficient decontamination product.

Chloramine solutions are usually studied by spectroscopic or colorimetric methods [12]. However, as MS is a broadband technique and is able to analyse multiple compounds at the same time, there is interest for MS analysis of those compounds. Chloramines analysis by EI-MIMS was first presented by Kotiaho et al. in 1991 [13]. Subsequent studies using similar methods presented detection limits down to $0.08 \mathrm{mg} / \mathrm{L}$ [14,15] and down to $2 \mu \mathrm{g} / \mathrm{L}$ for a trap-and-release MIMS [16]. Senthilmohan et al. [17] presented in 2008 the analysis of monochloramine as a marker for inflammation by direct analysis of the exhaled breath gas at atmospheric pressure. Chemical ionization, alternatively by $\mathrm{O}_{2}{ }^{+}, \mathrm{NO}^{+}$ and $\mathrm{H}_{3} \mathrm{O}^{+}$, in a SIFT-MS instrument was used. The same group presented a heated system to improve signal a few years later [18].

We present here the study of ammonia and monochloramine by MIMS using CI and an FTICR instrument. In addition to the technical aspects of our development, there is much interest in observing and understanding the chemical interactions of the studied species within the membrane. Both monochloramine and ammonia presented unexpected behavior. This study addresses the reasons for those phenomena.

\section{Results}

\subsection{Ammonia Permeation}

\subsubsection{Diffusion and Enrichment}

Ammonia is detected at a unique mass of $18.034 \mathrm{u}$ corresponding to $\mathrm{NH}_{4}{ }^{+}$ion. The temporal profile of $\mathrm{NH}_{4}{ }^{+}$signal presents a regular step form, that is common in MIMS, denoting a limited uptake of the compound in the feed solution. Figure 1 presents the calibration curve of the signal for increasing ammonia concentrations for basic solutions. The response is linear and the enrichment $\beta$, defined as the slope of the curve, is $5.5 \pm 0.3$. As expected for a polar compound, the value is low. It is in the same order of magnitude as methanol $[7,13]$.

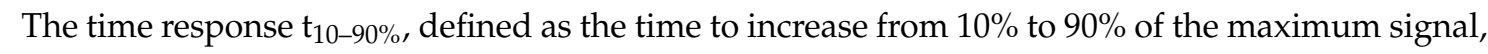
is nearly $20 \mathrm{~min}$ for the $125 \mu \mathrm{m}$ PDMS membrane. The diffusion coefficient $\mathrm{D}_{\mathrm{NH} 3}$ of $\mathrm{NH}_{3}$ in PDMS at $20{ }^{\circ} \mathrm{C}$ is estimated from $\mathrm{t}_{10-90 \%}$ using Equation (1):

$$
t_{10-90 \%}=0.237 \frac{l^{2}}{D}
$$

$\mathrm{D}_{\mathrm{NH} 3}$ is $(0.027 \pm 0.006) 10^{-6} \mathrm{~cm}^{2} \cdot \mathrm{s}^{-1}$. This denotes a particularly slow diffusion rate, when compared to methanol which has approximately the same size as ammonia [7]: the diffusion coefficient of methanol under the same conditions is $\mathrm{D}_{\mathrm{MeOH}}=2.14 \times 10^{-6} \mathrm{~cm}^{2} \cdot \mathrm{s}^{-1}$. There is little data on ammonia diffusion in PDMS membranes: two different studies estimated the diffusion coefficient to $2.1 \times 10^{-6} \mathrm{~cm}^{2} \cdot \mathrm{s}^{-1}$ [19] and $4.2 \times 10^{-6} \mathrm{~cm}^{2} \cdot \mathrm{s}^{-1}$ [20] for pure gas samples. In the first study, the authors observed a considerably slower response when the gas in front of the PDMS was switched from ammonia to air, approximately three times slower than the ammonia increase when switching 
back to ammonia. They suggested that interactions between the membrane and ammonia molecules were in play.

The diffusion coefficient obtained in this study in aqueous solution is two orders of magnitude lower than for gas samples. The aqueous solution is probably the reason for that difference. The water being the solvent, there is no barrier to its permeation, the consequence is the swelling of the material due to the presence of water molecules in the free volume of the PDMS structure. Ammonia is known to form clusters in water. Formation of ammonia-water clusters [20,21] may explain the difference observed and the much longer permeation time determined in our experiments. Clusters of alcohols were described in PTFE polymers [22]. The main consequence of cluster formation was the long diffusion time in the polymer compared to non-clustering compounds such as acetone. In PDMS, methanol solutions do not react as methanol gas in PTFE, as it permeates rapidly and enrichment is low. It denotes a high diffusion coefficient and low solubility in PDMS [7]. The long time response obtained for ammonia in PDMS is not an expected feature for a small molecule, as it should behave like methanol. Clusters could form in the membrane or at the interface and diffuse slowly due to their large section. However, detection of clusters with our instrument is not possible as the low pressure maintained in the MS chambers is too low to keep the clusters structure and desolvation occurs before it reaches the ion source.

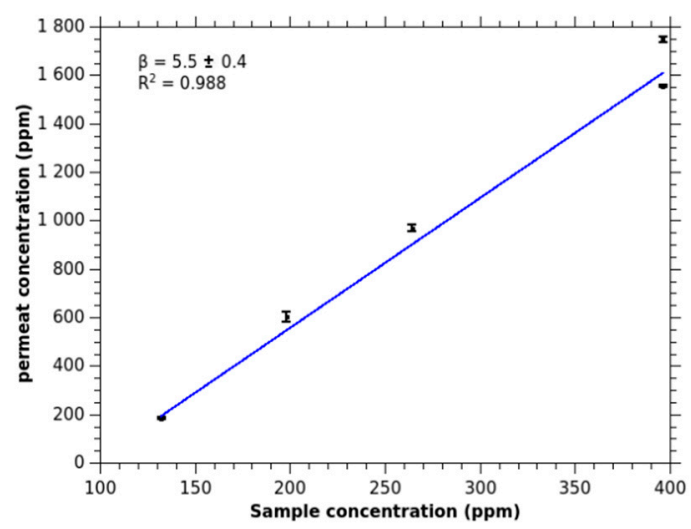

Figure 1. Calibration of ammonia signal as calculated from the ion signal $(m / z$ 18.034) for different feed concentrations (molar fraction in $\mathrm{ppm}$ ). The $\mathrm{pH}$ of the solutions are set to 10.5.

\subsection{2. $\mathrm{pH}$ Influence on Ammonia Signal}

Figure 2 presents evolution of ammonia signal for different $\mathrm{pH}$ values. The ammonia signal drops at acidic $\mathrm{pH}$. The observed trend is similar to the variation of the ammonium dissociation coefficient $\alpha_{\mathrm{NH} 3}$ where:

$$
\alpha_{N H 3}=\frac{K_{a}}{h+K_{a}}
$$

where $K_{a}$ is the acidity constant $(\mathrm{pKa}=9.24)$ and $h$ is the hydronium ion concentration $\left[\mathrm{H}_{3} \mathrm{O}^{+}\right]$. The decrease of ammonia signal is centered on $\mathrm{pKa}$. At a $\mathrm{pH}$ below the $\mathrm{pKa}$, the ammonium form prevails in the feed solution. Ammonia is then in its ionic form $\mathrm{NH}_{4}{ }^{+}$, this prevents permeation of the species in the hydrophobic membrane. Ion formation in the feed solution inhibits the neutral species from transferring through the membrane. To enable ammonia detection in an aqueous solution, the $\mathrm{pH}$ has then to be set to values above the pKa. 


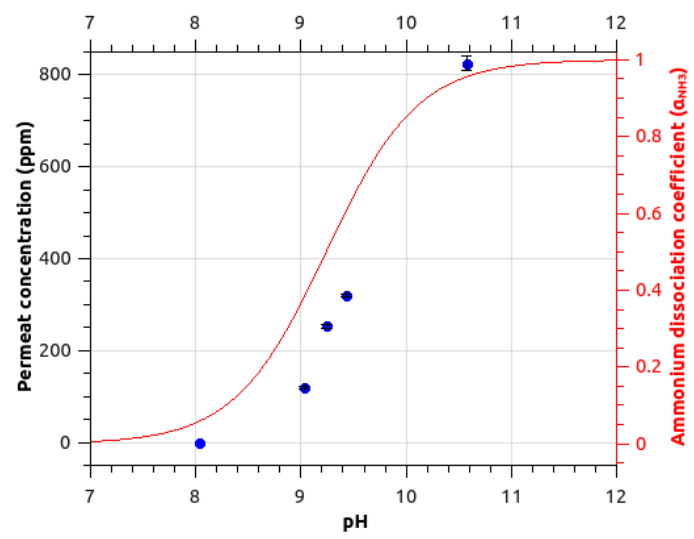

Figure 2. Ammonia signal ( $m / z$ 18.034) measured (blue points) for different $\mathrm{pH}$ around the $\mathrm{pKa}$. The theoretical ratio of $\mathrm{NH}_{3}$ is superimposed as a red line (calculated for a pKa of 9.24) on the right scale.

\subsection{Monochloramine Permeation}

Protonated monochloramine presents two peaks at $\mathrm{m} / z 51.995$ and $\mathrm{m} / z 53.992$ due to the isotopic distribution of the chlorine atom. Signal of $m / z 51.995$ is higher than the $m / z 53.992$ signal as expected of the abundance of ${ }^{35} \mathrm{Cl}$ versus ${ }^{37} \mathrm{Cl}$. At low concentrations, $m / z 51.995$ may be observed above the noise signal, whereas $m / z 53.992$ is not visible. Then, instead of considering the signal of protonated monochloramine $\mathrm{NH}_{3} \mathrm{Cl}^{+}$as the sum of $m / z 51.995$ and $m / z 53.992$ signals, we preferred to reconstruct the signal from the major peak of the isotopic distribution, i.e., $m / z 51.995$. We then consider that:

$$
S\left[\mathrm{NH}_{3} \mathrm{Cl}^{+}\right]=\frac{S[m / z 52]}{a b\left[{ }^{35} \mathrm{Cl}\right]}
$$

where $S\left[\mathrm{NH}_{3} \mathrm{Cl}^{+}\right]$is the reconstructed signal of protonated monochloramine, $S[\mathrm{~m} / z$ 52] is the signal of $\mathrm{m} / z 51.995$ ion, and $a b\left[{ }^{35} \mathrm{Cl}\right]=75.77 \%$ is the abundance of chlorine 35 .

From the reconstructed signal, as we use chemical ionization, it is possible to evaluate the concentration of the permeate gas knowing the capture rate constant $k_{C}$ [18]. We used the value calculated by Senthiloman et al. [17]: $k=3.0 \times 10^{-9} \mathrm{~cm}^{3} \cdot \mathrm{s}^{-1}$.

Figure 3 presents the calibration curve of the concentration of monochloramine in the permeate gas for different monochloramine concentrations in the feed solution. The monochloramine signal presents a linear response. The enrichment $\beta$ is the slope of the calibration curve. The value of the enrichment, $\beta=1.2$, is low as monochloramine presents a moderate to slow diffusivity in PDMS and as it is soluble in water. It is in agreement with its low partition coefficient logKow estimated at $-0.091 \pm 0.350$ (Calculated using Advanced Chemistry Development (ACD/Labs) Software V11.02).

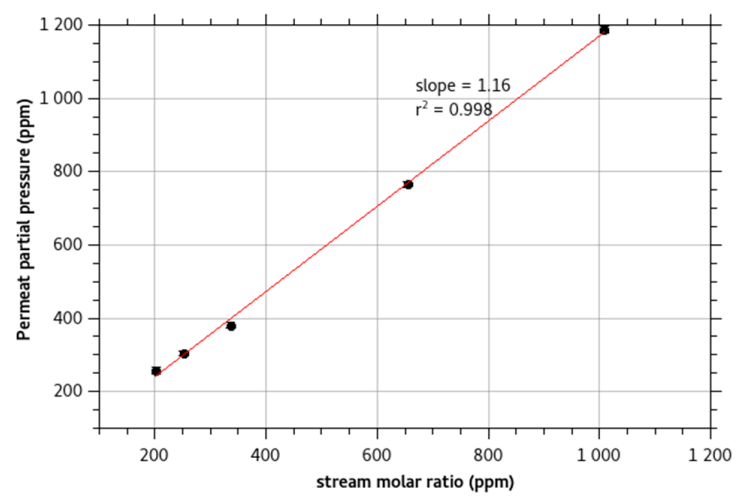

Figure 3. Monochloramine permeate concentration for different feed solution concentration. The line is the calculated calibration curve of the signal. The slope is the enrichment of the membrane. 
Monochloramine $\mathrm{NH}_{2} \mathrm{Cl}$ permeates through the membrane at a moderate rate. Contrary to steady state value, transient signal fitting is coarse as $\mathrm{NH}_{2} \mathrm{Cl}$ MIMS response is slightly different from a regular MIMS response. Indeed, first a fast response is observed, the $m / z 51.995$ signal increases rapidly. After that first phase, a second longer phase is observed before stabilization of the signal (Figure 4a). The presence of that second phase decreases the value of the diffusion coefficient.
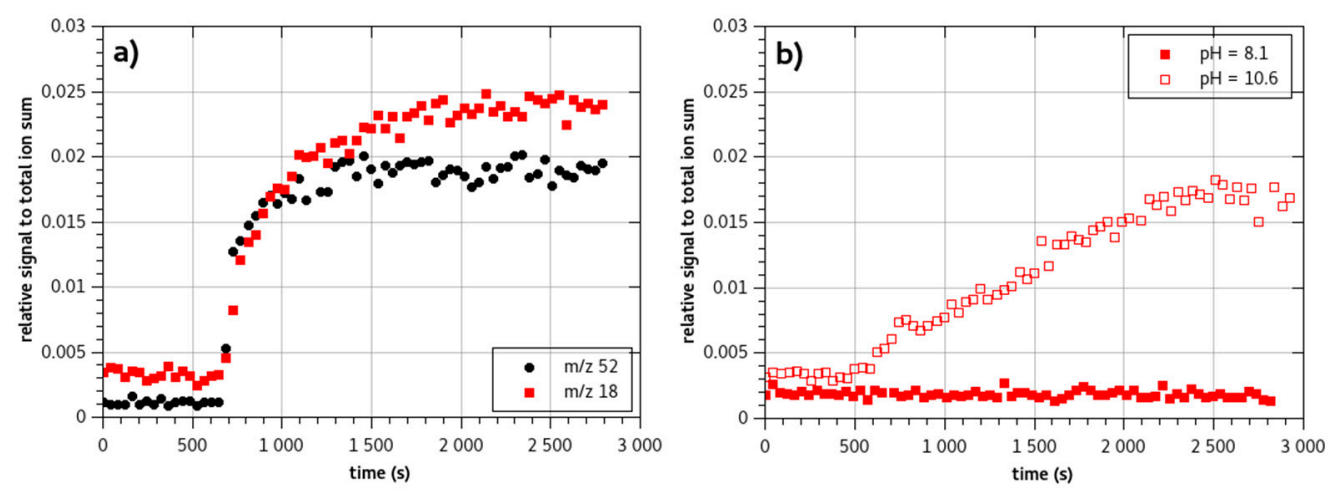

Figure 4. Time responses of the membrane system to (a) a solution of monochloramine $\left(\mathrm{NH}_{3} \mathrm{Cl}^{+} \mathrm{m} / z\right.$ 52 -black dots- and $\mathrm{NH}_{4}{ }^{+} \mathrm{m} / z 18$-red squares- are presented) prepared at $\mathrm{pH} 8.1$, (b) two ammonia solutions at $\mathrm{pH} 8.1$ (filled red squares) and $\mathrm{pH} 10.6$ (open red squares). Ammonia stock solution is added in the same quantity in the three solutions (solutions are prepared from $150 \mu \mathrm{L}$ of ammonia stock solution in $200 \mathrm{~mL}$ water).

\section{Origin of the Observed $\mathrm{NH}_{4}{ }^{+}$ion Signal for $\mathrm{NH}_{2} \mathrm{Cl}$ Solutions}

Concomitantly to the appearance of the protonated monochloramine signal, in pure monochloramine solutions, a well-marked signal of $\mathrm{NH}_{4}{ }^{+}$is measured. The values of the latter signal are as high as the $\mathrm{NH}_{3} \mathrm{Cl}^{+}$signal (Figure 4a). Moreover, it presents a steady increase with increase of monochloramine concentration in the feed.

The presence of the $\mathrm{NH}_{4}{ }^{+}$ion was not expected as earlier monochloramine MIMS experiments did not show this feature. Electron ionization (EI) is common in MIMS and monochloramine has been studied mainly using that ionization method. In EI-MIMS, $\mathrm{NH}_{2} \mathrm{Cl}^{+}$was generally the only product formed at $70 \mathrm{eV}$. Moreover, the EI product $\mathrm{NH}_{2} \mathrm{Cl}^{+}$is quite stable as $\mathrm{CID}$ measurement did not exhibit strong fragmentation [12]. $\mathrm{NH}_{2}{ }^{+}$is formed but with a low branching ratio $(7 \%)$.

The presence of that ion may be due to three different phenomena:

1. at the working $\mathrm{pH}$, dissociation is partial and presence of $m / z 18.034$ is due to the transfer of ammonia in the PDMS membrane;

2. reactivity of the protonated monochloramine occurs in the ICR cell, either by dissociation or secondary reaction;

3. dissociation of the neutral monochloramine happens somehow in-between the solubilization step in the PDMS membrane and ionization in the ICR cell.

These hypotheses are successively studied below.

\subsection{Is It Due to Permeation of $\mathrm{NH}_{3}$ from the Feed Solution?}

As demonstrated previously (Figure 2), permeation of substances is dependent on the form of the species (neutral or ionic). The $\mathrm{pH}$ of the solution is then established to a value for which ammonia is represented by its acid form $\mathrm{NH}_{4}{ }^{+}$. The $\mathrm{pH}$ of the feed solutions were then all set to values below the $\mathrm{pKa}(\mathrm{pH}$ 8.1). Using the same concentration of ammonia, we compared solutions of chloramine and ammonia at pH 8.1 (red squares on Figure 4a,b). No $m / z$ 18.034 signal could be evidenced when analyzing the ammonia feed solution. On the contrary, the monochloramine solution exhibited a 
strong $m / z 18.034$ signal. The ammonia that may be present in the feed solution is then not bound to permeate through the membrane at the $\mathrm{pH}$ of the solution.

Another interpretation would be to consider that at the vicinity of the membrane, as monochloramine is consumed by solubilization in the PDMS, a disequilibrium would occur. The difference of solubilization should then modify the $\mathrm{pH}$ in the limit layer. The consumption of $\mathrm{NH}_{2} \mathrm{Cl}$ increases $\mathrm{HO}^{-}$formation, $\mathrm{pH}$ may then increase locally as we didn't use a buffer solution to set the $\mathrm{pH}$. Figure 4 presents the time response of a chloramine solution (Figure 4a) and ammonia solution (Figure $4 \mathrm{~b}$ ) at the same concentration for a basic $\mathrm{pH}$ 10.6. The two solutions exhibit significantly different time responses for ammonia: the $\mathrm{NH}_{4}{ }^{+}$signal from monochloramine analysis is at least three times shorter than the $\mathrm{NH}_{4}{ }^{+}$signal from ammonia analysis. If ammonia were formed locally in the feed water solution, the time response of the $m / z 18.034$ from monochloramine solutions should be of the same order of magnitude or may be delayed compared to ammonia solution response. On the contrary, the $\mathrm{NH}_{4}{ }^{+}$ signal observed from monochloramine solution appears rapidly.

Therefore, it is probable that the $\mathrm{NH}_{4}{ }^{+}$signal observed is not due to ammonia permeation itself through the membrane.

\subsection{Is It Due to Ion-Molecule Reactivity?}

When looking to MIMS response of $\mathrm{NH}_{3} \mathrm{Cl}^{+}$and $\mathrm{NH}_{4}{ }^{+}$for a monochloramine solution (Figure 4a), it appears that permeation times of both ions are quite similar. It is then possible that the observed $\mathrm{NH}_{4}{ }^{+}$is due to a phenomenon occurring in the vacuum chamber after monochloramine pervaporation.

Figure 5 shows the dependency of the transient and stable response of the MIMS signal to monochloramine solutions of increasing concentrations with the $\mathrm{H}_{3} \mathrm{O}^{+}$signal. The $\mathrm{NH}_{4}{ }^{+}$signal presents a pattern consistent with a reaction scheme such as:

$$
\begin{aligned}
\mathrm{NH}_{2} \mathrm{Cl} & +\mathrm{H}_{3} \mathrm{O}^{+} \rightarrow \mathrm{NH}_{3} \mathrm{Cl}^{+}+\mathrm{H}_{2} \mathrm{O} \\
& \rightarrow \mathrm{NH}_{4}^{+}+\mathrm{HOCl} \\
\mathrm{NH}_{3} \mathrm{Cl}^{+} & +\mathrm{NH}_{2} \mathrm{Cl} \rightarrow \mathrm{NH}_{4}^{+}+\mathrm{NHCl}_{2}
\end{aligned}
$$

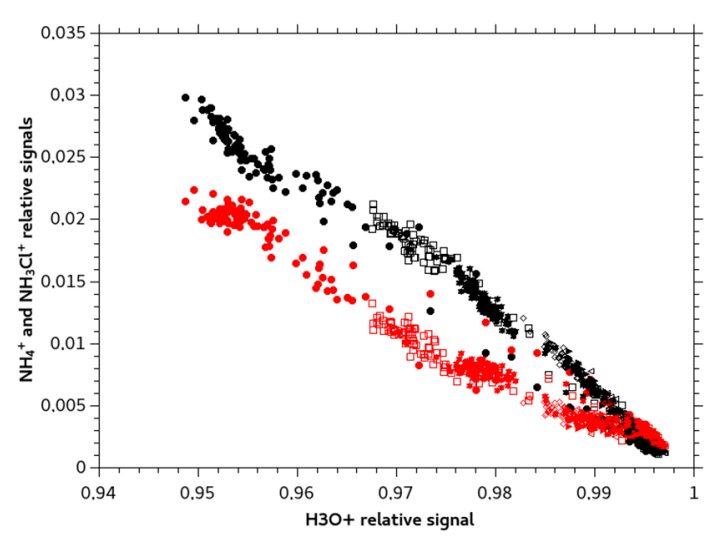

Figure 5. $\mathrm{NH}_{4}{ }^{+}\left(m / z\right.$ 18) signal in red and $\mathrm{NH}_{3} \mathrm{Cl}^{+}(m / z 52)$ signal in black compared to $\mathrm{H}_{3} \mathrm{O}^{+}$signal (precursor) during transient and stable MIMS response for different concentrations.

All three reactions are exothermic [23,24]. Reactions (4) and (5) are parallel, as no delay for $\mathrm{NH}_{4}{ }^{+}$ formation was highlighted: at low reaction extent both ion products are observed. Reaction (6) is a secondary reaction that would explain the increase of $\mathrm{NH}_{4}{ }^{+}$signal compared to $\mathrm{NH}_{3} \mathrm{Cl}^{+}$signal for higher reaction extent.

As the permeate is mainly made of water, a reaction with water may be considered:

$$
\mathrm{NH}_{3} \mathrm{Cl}^{+}+\mathrm{H}_{2} \mathrm{O} \rightarrow \mathrm{NH}_{4}^{+}+\mathrm{HOCl}
$$


From formation enthalpies $[23,25]$, we calculated a reaction enthalpy of $0.5 \mathrm{~kJ} \cdot \mathrm{mol}^{-1}$. The reaction is thermoneutral, reaction rate coefficient is then likely to be slow. The yield of reaction (7) is then bound to be much lower than the amount of ammonia signal.

Unfortunately, the reactivity of $\mathrm{NH}_{2} \mathrm{Cl}$ and $\mathrm{H}_{3} \mathrm{O}^{+}$is difficult to study as $\mathrm{NH}_{2} \mathrm{Cl}$ is nearly never formed as a pure product. To overcome this limitation, we proposed to study the products obtained using different precursors: 2 proton donor precursors (para-difluorobenzene $\mathrm{F}_{2} \mathrm{C}_{6} \mathrm{H}_{4}$ [26] and 1,3,5-trimethylbenzene $\left.\left(\mathrm{CH}_{3}\right)_{3} \mathrm{C}_{6} \mathrm{H}_{3}\right)$ and a potential hydride or chloride abstraction precursor $\mathrm{CF}_{3}{ }^{+}$[27]. Proton affinity (PA) of monochloramine is $797.05 \mathrm{~kJ} \cdot \mathrm{mol}^{-1}$ [23], it should then react by PTR with $\mathrm{H}_{3} \mathrm{O}^{+}$as observed, and with $\mathrm{F}_{2} \mathrm{C}_{6} \mathrm{H}_{5}{ }^{+}$. On the contrary, PA of 1,3,5-trimethylbenzene is higher. The reactivity with that ion should then be limited. The reactivity of $\mathrm{CF}_{3}{ }^{+}$is only known for $\mathrm{NH}_{3}$ [28]:

$$
\mathrm{NH}_{3}+\mathrm{CF}_{3}^{+} \rightarrow \mathrm{CF}_{2} \mathrm{NH}_{2}^{+}+\mathrm{HF}
$$

The kinetic rate coefficient is $2.1 \times 10^{-9} \mathrm{~cm}^{3} \cdot \mathrm{s}^{-1}$.

Interestingly, the formation of $\mathrm{NH}_{4}{ }^{+}$is not prevented by a change of the precursor to higher PA (Table 1). Moreover, the observed products fit with a reactivity of ammonia with the PTR precursors, as the chosen precursors have all a PA below ammonia $\left(\mathrm{AP}\left(\mathrm{NH}_{3}\right)=853.6 \mathrm{~kJ} \cdot \mathrm{mol}^{-1}\right)$. Using $\mathrm{CF}_{3}{ }^{+}$, two products are also observed. The $\mathrm{CF}_{2} \mathrm{NH}_{2}{ }^{+}$ion is very probably due to Reaction (9). Reaction of chloramine and $\mathrm{CF}_{3}{ }^{+}$gives rise to a similar reaction:

$$
\mathrm{NH}_{2} \mathrm{Cl}+\mathrm{CF}_{3}{ }^{+} \rightarrow \mathrm{CF}_{2} \mathrm{NHCl}^{+}+\mathrm{HF}
$$

From those experiments, it appears that the ammonium signal is probably due to direct ionization of ammonia and not from Reaction (5).

Occurrence of Reaction (6) was also tested. First, $\mathrm{NH}_{3} \mathrm{Cl}^{+}$ion is isolated in the ICR cell by the excitation and the ejection of the other ions present in the cell. Then, a pulse of permeate is injected in the ICR chamber. Time is left for the reaction to occur. Finally, no $\mathrm{NH}_{4}{ }^{+}$was detected. Ricci and Rosi [23], studying the reactivity of $\mathrm{NH}_{3} \mathrm{Cl}^{+}$produced by $\mathrm{CI} / \mathrm{CH}_{4}$ in a FTICR apparatus, observed the ion $\mathrm{NH}_{2} \mathrm{Cl}_{2}{ }^{+}$as a product of a secondary reaction (formed by $\mathrm{Cl}^{+}$transfer). Likewise, they did not report $\mathrm{NH}_{4}{ }^{+}$formation.

The observed ammonia signal is then probably not due to a secondary reaction of ionized $\mathrm{NH}_{2} \mathrm{Cl}$. Those results tend to point to an alternate scenario: ammonia is present in the cell before ionization.

Table 1. Products observed by ion-molecule reaction of the permeate of a monochloramine solution and 4 precursors. 3 of them are proton transfer precursors.

\begin{tabular}{ccccc}
\hline Neutral Precursor & Ionic Precursor & PA [29] (kJ· mol $\left.{ }^{-1}\right)$ & Product 1 & Product 2 \\
\hline $\mathrm{H}_{2} \mathrm{O}$ & $\mathrm{H}_{3} \mathrm{O}^{+}$ & 691 & $\mathrm{NH}_{3} \mathrm{Cl}^{+}$ & $\mathrm{NH}_{4}{ }^{+}$ \\
$\mathrm{F}_{2} \mathrm{C}_{6} \mathrm{H}_{4}$ & $\mathrm{~F}_{2} \mathrm{C}_{6} \mathrm{H}_{5}{ }^{+}$ & 718.7 & $\mathrm{NH}_{3} \mathrm{Cl}^{+}$ & $\mathrm{NH}_{4}{ }^{+}$ \\
$\left(\mathrm{CH}_{3}\right)_{3} \mathrm{C}_{6} \mathrm{H}_{3}$ & $\left(\mathrm{CH}_{3}\right)_{3} \mathrm{C}_{6} \mathrm{H}_{4}{ }^{+}$ & 853.6 & $\mathrm{CH}_{4}^{+}$ \\
$\mathrm{CF}_{4}$ & $\mathrm{CF}_{3}{ }^{+}$ & - & $\mathrm{CF}_{2} \mathrm{NHCl}^{+}$ & $\mathrm{CF}_{2} \mathrm{NH}_{2}{ }^{+}$ \\
\hline
\end{tabular}

\subsection{Is Neutral Monochloramine Reacting in the Vacuum Chamber?}

From the previous experiments, we could not explain the presence of $\mathrm{NH}_{4}{ }^{+}$peak from ammonia in the solution or from the ionization of monochloramine. Ammonia is then probably formed in-between from a neutral reaction:

$$
\mathrm{NH}_{2} \mathrm{Cl}+\mathrm{H}_{2} \mathrm{O} \rightleftarrows \mathrm{NH}_{3}+\mathrm{HOCl}
$$

The reactivity of neutrals on surfaces may take place inside the vacuum cell. However, probability of encountering a surface or a molecule is low in a low pressure FTICR. If such a phenomenon occurred, it would not explain the high proportion of $m / z 18.034$ peak. Moreover, one could argue that the problem is due to an inner problem of our instrument. That is partially true only. We tested our 
membrane system on two different FTICR instruments. Despite being similar, their internal structure and in particular the cell is different in terms of material used. Both exhibited a strong $\mathrm{NH}_{4}{ }^{+}$signal proportional to $\mathrm{NH}_{2} \mathrm{Cl}$ concentration.

The probable reason for the presence of ammonia in the vacuum chamber is a reaction occurring in the membrane itself. As explained, ammonia is not permeating through the membrane as it is mainly under its ammonium form. This induces a disequilibrium inside the PDMS membrane with an excess of monochloramine compared to ammonia and hypochlorite. $\mathrm{NH}_{2} \mathrm{Cl}$ may then react with water inside the membrane to form $\mathrm{NH}_{3}$ and $\mathrm{HOCl}$ as in Equation (10). $\mathrm{HOCl}$ has a low proton affinity [30], it cannot react with the proton transfer precursors used in this study.

An in-membrane reactivity may explain why the ammonia signal appears at the same time as the monochloramine signal (Figure 4a). Besides, it appears that the $m / z 18.034$ signal generally keeps on steadily increasing even after monochloramine signal reached the steady state. This feature would be due to transfer of ammonia in the membrane from where it was formed originally. Diffusion of ammonia being slower than monochloramine, response of $m / z 18.034$ signal would involve two diffusion parameters, one due to monochloramine diffusion and the second due to ammonia diffusion in the membrane. The appearance of the ammonia signal is then a two-step process.

Finally, experiments of Provin and Fujii [31] in a microdevice suggested that reactivity inside a PDMS membrane between different species is possible with no chemical alteration of the membrane.

\section{Materials and Methods}

\subsection{Chloramine and Ammonia Solutions}

A stock solution of ammonia was prepared from $20 \mathrm{~mL}$ of concentrated $\mathrm{NH}_{4} \mathrm{OH}$ solution ( $28 \%$ Reagent grade, VWR Prolabo) adjusted to $50 \mathrm{~mL}$ with deionized water. To prepare ammonia solution for calibration, various volumes of the stock solution were added in a $200 \mathrm{~mL}$ vial, and $\mathrm{pH}$ was adjusted to 10.5 .

A stock solution of sodium hypochlorite was prepared daily by diluting a purchased concentrated solution (14\% active chlorine, VWR Prolabo) in deionized water. Sodium hypochlorite is known to be unstable in solution. Decomposition of $\mathrm{HOCl}$ occurs at moderate speed. Therefore, the sodium hypochlorite solution was titrated every week to evaluate its concentration.

Monochloramine was synthesized in-situ by addition of the diluted solution of sodium hypochlorite to the diluted ammonia solution at molar ratio 1:1 (ammonia/chlorine) under alkaline conditions ( $\mathrm{pH} \sim 8.5$ ). Different concentrations were achieved by preparing the solution using different volume of the two solutions and mixing them in a $200 \mathrm{~mL}$ vial completed with deionized water.

Under those conditions, only monochloramine should form through the reaction [14]:

$$
\mathrm{NH}_{3}+\mathrm{ClO}^{-} \rightleftarrows \mathrm{NH}_{2} \mathrm{Cl}+\mathrm{HO}^{-}
$$

During MIMS analysis, absence of di- or tri-chloramine was systematically checked.

Monochloramine is not stable in solution and produces $\mathrm{NH}_{3}$ or dichloramine in standard solutions. $\mathrm{NH}_{2} \mathrm{Cl}$ solutions were then prepared daily and the concentrations of monochloramine were measured in the solution using the DPD ( $N, N$-diethylphenylene-1,4-diamine) method [32]. DPD reagent is oxidized by chloramine. The oxidation product is red and absorbs visible light at $510 \mathrm{~nm}$. It is then titrated by spectroscopy or by ammonium and iron sulfate until total discoloration.

The $\mathrm{pH}$ of the solution was monitored by a Lab $860 \mathrm{pH}$-meter (Schott Instruments). Adjustment of $\mathrm{pH}$ value was obtained by addition of concentrated solutions of $\mathrm{H}_{2} \mathrm{SO}_{4}$ and $\mathrm{NaOH}$.

\subsection{Membrane Inlet}

The membrane inlet has been described in a previous work [7]. In brief, the membrane material is made of a PDMS elastomer supplied by Goodfellow SARL (Lille, France). Different thicknesses are available. Optimal thickness is $125 \mu \mathrm{m}$ as thinner membranes break easily under our experimental 
conditions. The PDMS film is held between two stainless steel plates. A channel $40 \mathrm{~mm} \times 1.5 \mathrm{~mm}$ channel is extruded in each plate. The interface between the sample stream and the vacuum cell is then $60 \mathrm{~mm}^{2}$. Two hollow copper sheets, filled with water at $20^{\circ} \mathrm{C}$ from a controlled temperature water bath, set the temperature of the membrane system.

One side of the membrane is connected to the water feed at $80 \mathrm{~mL} \cdot \mathrm{min}^{-1}$, and the other side is directly connected to the vacuum chamber of the mass spectrometer.

\subsection{Compact Low-Field FT-ICR Mass Spectrometer and Chemical Ionization}

The mass spectrometer is based on a Fourier transform ion cyclotron resonance (FT-ICR) analyzer. The coupling and performance of the instrument have been extensively described elsewhere $[7,26,27,33,34]$. The instrument has two vacuum chambers: the ICR vacuum chamber and the waste chamber. The latter enables generation of a continuous flow at low pressure. The two vacuum chambers are linked to the MIMS permeate exit by a three-way valve that directs the flow to the buffer vacuum chamber, for continuous pumping of the membrane, or to the ICR vacuum chamber, for a few 100 ms during ionization.

This technology enables chemical ionization in the ICR cell. Ion formation occurs by means of sequential operations in 3 to $5 \mathrm{~s}$. Briefly, it is as following: 1. neutral precursor is introduced: $\mathrm{H}_{2} \mathrm{O}$ for example; 2. molecules are ionized by an electron beam at $70 \mathrm{eV}: \mathrm{H}_{2} \mathrm{O}^{+}$is formed; 3. time is left for secondary reactivity to occur: ion-molecule reactivity of $\mathrm{H}_{2} \mathrm{O}^{+}$and $\mathrm{H}_{2} \mathrm{O}$ produces $\mathrm{H}_{3} \mathrm{O}^{+}$; 4. permeate is introduced for a few $100 \mathrm{~ms}$ : permeate contains a molecule $\mathrm{M}$; 5. time for reactivity to occur: proton transfer reaction gives $\mathrm{MH}^{+} ; 6$. detection.

For this study different precursors were used. $\mathrm{H}_{3} \mathrm{O}^{+}$is formed from $\mathrm{H}_{2} \mathrm{O}$ directly by electron ionization [10]. $\mathrm{F}_{2} \mathrm{C}_{6} \mathrm{H}_{5}{ }^{+}$and $\left(\mathrm{CH}_{3}\right)_{3} \mathrm{C}_{6} \mathrm{H}_{4}{ }^{+}$are formed by proton transfer reaction of the neutral, respectively 1,4-difluorobenzene and 1,3,5-trimethylbenzene, and $\mathrm{H}_{3} \mathrm{O}^{+}$, adding a repetition of step 4 and 5, one for the precursor formation ( $\mathrm{M}$ is the precursor) and one for permeate introduction [26]. $\mathrm{CF}_{3}{ }^{+}$is formed by electron ionization of $\mathrm{CF}_{4}$ [27].

Two compact FTICR mass spectrometers have been used: Btrap2, for the study on different precursors, and MICRA (mobile ICR analyzer) [18] for the other experiments. Btrap2 is an instrument developed by AlyXan (Juvisy-sur-Orge, France): it is fully automated and uses a $1 \mathrm{~T}$ permanent magnet. MICRA's magnet is $1.24 \mathrm{~T}$.

The use of an FTICR makes it possible to measure exact masses, with an accuracy of $0.01 \mathrm{u}$ for Btrap2 and $0.005 \mathrm{u}$ for MICRA, and to identify the ions. Typically, we are able to differentiate $\mathrm{NH}_{4}{ }^{+}$ $(18.034 \mathrm{u})$ and $\mathrm{H}_{2} \mathrm{O}^{+}(18.011 \mathrm{u})$. Quantification of the compounds in the permeate is possible since ion-molecule reaction conditions are controlled in the cell (pressure, temperature, reaction time) [10]. Rate coefficients for ammonia [35] and monochloramine [17] are taken from literature.

\section{Conclusions}

This study presents new results on chloramine and ammonia detection by MIMS in aqueous solutions. The steady state response of ammonia and monochloramine are in accordance with their high solubility in water. However, the products detected for monochloramine sample and the time responses for both samples were not as expected for low molecular mass species.

First, a long time response was observed for ammonia solutions. Presence of water in the membrane is probably the reason for that result, as it induces the formation of ammonia clusters, what would drastically decrease the diffusion rate by increasing the ammonia cross section.

Second, in PTR mode, monochloramine feed solution presented two ion products: protonated monochloramine $\mathrm{NH}_{3} \mathrm{Cl}^{+}$and $\mathrm{NH}_{4}{ }^{+}$. Whereas the first ion is the common protonated $\mathrm{MH}^{+}$ion, the latter ion $\mathrm{NH}_{4}{ }^{+}$was not expected. The $m / z 18.034$ ion signal appeared at the same rate as the $\mathrm{NH}_{3} \mathrm{Cl}^{+}$signal and its intensity was in the same order of magnitude as $\mathrm{NH}_{3} \mathrm{Cl}^{+}$signal. As the $\mathrm{pH}$ was below $\mathrm{pKa}$, the $\mathrm{NH}_{4}{ }^{+}$was not due to ammonia permeation through the membrane. We studied the reactivity of the permeate gas and neutral monochloramine with various precursors. All exhibited a 
signal due to ammonia reactivity. Reactivity of the neutral $\mathrm{NH}_{2} \mathrm{Cl}$ may then occur, probably in the membrane. $\mathrm{NH}_{2} \mathrm{Cl}$ is an unstable compound that tends to dissociate in an excess of water into $\mathrm{NH}_{3}$ and $\mathrm{HOCl}$. This phenomenon may take place in the membrane as the medium lacks of ammonia.

The presence of the protonated ammonium ion has to be acknowledged when measuring monochloramine in real samples. $\mathrm{pH}$ of those solutions are not all set to a specific value, particularly when working in real-time, ammonia may then be present under its basic form. Moreover, presence of ammonia from different sources in the solutions is probable. The feature presented here leads to take with caution the precision of the measurement for such solutions as the ratio of $\mathrm{NH}_{3} \mathrm{Cl}^{+}$and $\mathrm{NH}_{4}{ }^{+}$is not steady and vary slightly with concentration. Direct sampling of headspace may be a better method, as stability of monochloramine in air is probably higher and as preconcentration effect of the MIMS system for monochloramine is limited.

More generally, the membrane in MIMS has to be taken into account when interpreting the data obtained. It should not be considered as a black box that has no influence on the products obtained. The membrane is a chemical matrix that could be involved in the reactivity of the studied compounds as observed in our study.

Author Contributions: E.L., M.H. and H.M. contributed to the conceptualization, funding acquisition and supervision of the project. A.M.A.-I. and J.L. conducted the investigation. Formal analysis, data curation, methodology, visualization and writing (original draft) was conducted by E.L. M.H. and H.M. participated to writing through review and editing.

Funding: This research was funded by French Ministry of Economy (Ministère de l'Économie, des Finances et de l'Industrie), for the project AQUAREM under RAPID plan and Paris-Sud University under Attractivité plan.

Acknowledgments: The authors would like to thank AlyXan company for the use of their Btrap2 FTICR.

Conflicts of Interest: The authors declare no conflict of interest. The funders had no role in the design of the study; in the collection, analyses, or interpretation of data; in the writing of the manuscript, or in the decision to publish the results.

\section{Abbreviations}

$\begin{array}{ll}\text { MIMS } & \text { Membrane Inlet Mass Spectrometry } \\ \text { PDMS } & \text { Polydimethylsiloxane } \\ \text { VOC } & \text { Volatile Organic Compound } \\ \text { EI } & \text { Electronic Ionization } \\ \text { CI } & \text { Chemical Ionization } \\ \text { FT-ICR } & \text { Fourier Transform Ion Cyclotron Resonance } \\ \text { SIFT } & \text { Selected Ion Flow Tube } \\ \text { PTFE } & \text { PolyTetraFluoroEthylene } \\ \text { PTR } & \text { Proton Transfer Reaction }\end{array}$

\section{References}

1. Bier, M.E.; Cooks, R.G. Membrane interface for selective introduction of volatile compounds directly into the ionization chamber of a mass spectrometer. Anal. Chem. 1987, 59, 597-601. [CrossRef]

2. Krogh, E.; Gill, C.G. Membrane introduction mass spectrometry (MIMS): A versatile tool for direct, real-time chemical measurements. J. Mass Spectrom. 2014, 49, 1205-1213. [CrossRef] [PubMed]

3. Eschenbach, W.; Lewicka-Szczebak, D.; Stange, C.F.; Dyckmans, J.; Well, R. Measuring 15N Abundance and Concentration of Aqueous Nitrate, Nitrite, and Ammonium by Membrane Inlet Quadrupole Mass Spectrometry. Anal. Chem. 2017, 89, 6076-6081. [CrossRef] [PubMed]

4. Ketola, R.A.; Virkki, V.T.; Ojala, M.; Komppa, V.; Kotiaho, T. Comparison of different methods for the determination of volatile organic compounds in water samples. Talanta 1997, 44, 373-382. [CrossRef]

5. Short, R.T.; Fries, D.P.; Kerr, M.L.; Lembke, C.E.; Toler, S.K.; Wenner, P.G.; Byrne, R.H. Underwater mass spectrometers for in situ chemical analysis of the hydrosphere. J. Am. Soc. Mass Spectrom. 2001, 12, 676-682. [CrossRef] 
6. Hemond, H.; Camilli, R. NEREUS: Engineering concept for an underwater mass spectrometer. TrAC Trends Anal. Chem. 2002, 21, 526-533. [CrossRef]

7. Louarn, E.; Hamrouni, A.; Colbeau-Justin, C.; Bruschi, L.; Lemaire, J.; Heninger, M.; Mestdagh, H. Characterization of a membrane inlet interfaced with a compact chemical ionization FT-ICR for real-time and quantitative VOC analysis in water. Int. J. Mass Spectrom. 2013, 353, 26-35. [CrossRef]

8. Davey, N.G.; Bell, R.J.; Krogh, E.T.; Gill, C.G. A membrane introduction mass spectrometer utilizing ion-molecule reactions for the on-line speciation and quantitation of volatile organic molecules. Rapid Commun. Mass Spectrom. 2015, 29, 2187-2194. [CrossRef]

9. Blake, R.S.; Monks, P.S.; Ellis, A.M. Proton-Transfer Reaction Mass Spectrometry. Chem. Rev. 2009, 109, 861-896. [CrossRef]

10. Dehon, C.; Gaüzère, E.; Vaussier, J.; Heninger, M.; Tchapla, A.; Bleton, J.; Mestdagh, H. Quantitative analysis of a complex mixture using proton transfer reaction in an FTICR mass spectrometer. Int. J. Mass Spectrom. 2008, 272, 29-37. [CrossRef]

11. Soulard, M.; Bloc, F.; Hatterer, A. Diagrams of existence of chloramines and bromamines in aqueous solution. J. Chem. Soc. Dalton Trans. 1981, 2300-2310. [CrossRef]

12. Kinani, S.; Richard, B.; Souissi, Y.; Bouchonnet, S. Analysis of inorganic chloramines in water. $\operatorname{Tr} A C \operatorname{Trends}$ Anal. Chem. 2012, 33, 55-67. [CrossRef]

13. Kotiaho, T.; Lister, A.K.; Hayward, M.J.; Cooks, R.G. On-line monitoring of chloramine reactions by membrane introduction mass spectrometry. Talanta 1991, 38, 195-200. [CrossRef]

14. Shang, C.; Blatchley, E.R. Differentiation and Quantification of Free Chlorine and Inorganic Chloramines in Aqueous Solution by MIMS. Environ. Sci. Technol. 1999, 33, 2218-2223. [CrossRef]

15. Weaver, W.A.; Li, J.; Wen, Y.; Johnston, J.; Blatchley, M.R.; Blatchley, E.R., III. Volatile disinfection by-product analysis from chlorinated indoor swimming pools. Water Res. 2009, 43, 3308-3318. [CrossRef] [PubMed]

16. Riter, L.S.; Takáts, Z.; Charles, L.; Cooks, R.G. High surface area membrane introduction mass spectrometry for analysis of volatile and semi-volatile organic compounds in air. Rapid Commun. Mass Spectrom. 2001, 15, 1520-1524. [CrossRef]

17. Senthilmohan, S.T.; Kettle, A.J.; McEwan, M.J.; Dummer, J.; Edwards, S.J.; Wilson, P.F.; Epton, M.J. Detection of monobromamine, monochloramine and dichloramine using selected ion flow tube mass spectrometry and their relevance as breath markers. Rapid Commun. Mass Spectrom. 2008, 22, 677-681. [CrossRef]

18. Hu, W.-P.; Langford, V.S.; McEwan, M.J.; Milligan, D.B.; Storer, M.K.; Dummer, J.; Epton, M.J. Monitoring chloramines and bromamines in a humid environment using selected ion flow tube mass spectrometry. Rapid Commun. Mass Spectrom. 2010, 24, 1744-1748. [CrossRef]

19. Blyler, L.L.; Lieberman, R.A.; Cohen, L.G.; Ferrara, J.A.; Macchesney, J.B. Optical fiber chemical sensors utilizing dye-doped silicone polymer claddings. Polym. Eng. Sci. 1989, 29, 1215-1218. [CrossRef]

20. Makhloufi, C.; Roizard, D.; Favre, E. Reverse selective NH3/CO2 permeation in fluorinated polymers using membrane gas separation. J. Membr. Sci. 2013, 441, 63-72. [CrossRef]

21. Gadre, S.R.; Yeole, S.D.; Sahu, N. Quantum Chemical Investigations on Molecular Clusters. Chem. Rev. 2014, 114, 12132-12173. [CrossRef] [PubMed]

22. Jansen, J.C.; Friess, K.; Drioli, E. Organic vapour transport in glassy perfluoropolymer membranes: A simple semi-quantitative approach to analyze clustering phenomena by time lag measurements. J. Membr. Sci. 2011, 367, 141-151. [CrossRef]

23. Ricci, A.; Rosi, M. Gas-Phase Chemistry of $\mathrm{NH}_{\mathrm{x}} \mathrm{Cl}_{\mathrm{y}}{ }^{+}$. 1. Structure, Stability, and Reactivity of Protonated Monochloramine. J. Phys. Chem. A 1998, 102, 10189-10194. [CrossRef]

24. Ricci, A.; Rosi, M. Gas Phase Chemistry of $\mathrm{NH}_{\mathrm{x}} \mathrm{Cl}_{\mathrm{y}}{ }^{+}$Ions. II. Structure, Stability and Reactivity of Protonated Dichloramine. J. Phys. Chem. A 2000, 104, 5617-5624. [CrossRef]

25. Burgess, D.R.F. Thermochemical Data. In NIST Chemistry WebBook, NIST Standard Reference Database Number 69; Linstrom, P.J., Mallard, W.G., Eds.; NIST: Gaithersburg, MD, USA, 2018; Volume 20899.

26. Latappy, H.; Lemaire, J.; Heninger, M.; Louarn, E.; Bauchard, E.; Mestdagh, H. Protonated 1,4-difluorobenzene $\mathrm{C}_{6} \mathrm{H}_{5} \mathrm{~F}_{2}{ }^{+}$: A promising precursor for proton-transfer chemical ionization. Int. J. Mass Spectrom. 2016, 405, 13-23. [CrossRef]

27. Dehon, C.; Lemaire, J.; Heninger, M.; Chaput, A.; Mestdagh, H. Chemical ionization using $\mathrm{CF}_{3}^{+}$: Efficient detection of small alkanes and fluorocarbons. Int. J. Mass Spectrom. 2011, 299, 113-119. [CrossRef] 
28. Grandinetti, F.; Occhiucci, G.; Crestoni, M.E.; Fornarini, S.; Speranza, M. Ionic Lewis superacids in the gas phase. Part 2. Reactions of gaseous $\mathrm{CF}_{3}^{+}$with oxygen bases. Int. J. Mass Spectrom. Ion Process. 1993, 127, 123-135. [CrossRef]

29. Hunter, E.P.L.; Lias, S.G. Evaluated gas phase basicities and proton affinities of molecules: An update. J. Phys. Chem. Ref. Data 2009, 27, 413. [CrossRef]

30. Francisco, J.S.; Sander, S.P. Protonated hydrochlorous acid $\left(\mathrm{HOClH}^{+}\right)$: Molecular structure, vibrational frequencies, and proton affinity. J. Chem. Phys. 1995, 102, 9615. [CrossRef]

31. Provin, C.; Fujii, T. Reaction-diffusion phenomena in a PDMS matrix can modify its topography. Lab Chip 2011, 11, 2948-2954. [CrossRef]

32. Rodier, J.; Legube, B.; Merlet, N. L'analyse de L'eau, 9th ed.; Dunod: Paris, France, 2009; ISBN 978-2-10-007246-0.

33. Mauclaire, G.; Lemaire, J.; Boissel, P.; Bellec, G.; Heninger, M. MICRA: A compact permanent magnet Fourier transform ion cyclotron resonance mass spectrometer. Eur. J. Mass Spectrom. 2004, 10, 155-162. [CrossRef] [PubMed]

34. Lemaire, J.; Thomas, S.; Lopes, A.; Louarn, E.; Mestdagh, H.; Latappy, H.; Leprovost, J.; Heninger, M. Compact FTICR Mass Spectrometry for Real Time Monitoring of Volatile Organic Compounds. Sensors 2018, 18, 1415. [CrossRef] [PubMed]

35. Lindinger, W.; Hansel, A.; Jordan, A. On-line monitoring of volatile organic compounds at pptv levels by means of proton-transfer-reaction mass spectrometry (PTR-MS) medical applications, food control and environmental research. Int. J. Mass Spectrom. Ion Process. 1998, 173, 191-241. [CrossRef]

(C) 2018 by the authors. Licensee MDPI, Basel, Switzerland. This article is an open access article distributed under the terms and conditions of the Creative Commons Attribution (CC BY) license (http:/ / creativecommons.org/licenses/by/4.0/). 